\title{
Transferring Retail Format of Hybridization: A Case Study of UNIQLO in Mainland China
}

\author{
Lehua Yang
}

\begin{abstract}
The debate about standardization and adaptation of the transfer of retail formats is a key issue in the field of retail internationalization. While it has been recognized that "Glocalization" or "Hybridization" approach is significant in much of the existing literature. However, there is still a lack of knowledge regarding the competitive advantage for the standardization and adaptation in international retailers. A case study of the successful operation of UNIQLO in Mainland China helps in understanding why retailers do succeed in all international markets. The paper also identifies important factors in the strategies of "Hybridization". These include the concepts of "Standardization of specific advantage" and "creative adaptation" to the case study.
\end{abstract}

Index Terms - Standardization, adaptation, mainland China, Japan, transfer.

\section{INTRODUCTION}

Retailers are involved in a wide variety of international activities. In the past three decades, the study of international activities of large retailers have been narrowed to three main ways since the early reviews, including the long-established international sourcing of products and services, the operation of shops or other forms in more than one country, and the transfer of know-how and management expertise [1]-[4].

The research on international expansion has been dominated by empirical studies and lacks an adequate conceptual and theoretical framework. Some studies try to apply directly the theoretical studies in the internationalization of manufacturing, such as the international product life cycle (IPLC) theory that patterns international trade of products, developed by Vernon [5]. Besides, Dunning's Eclectic Theory [6], which focuses on advantages factors that influence international expansion. However, not all this work is of relevance to retailing, we need to develop a retail-specific theory.

Several researchers have explored global versus multinational retailers, a distinction related to standard versus adaptive expansion. However, it discusses only two format transfer possibilities: standardization and adaptation. There is still a lack of knowledge regarding the competitive advantage for the standardization and adaptation in international retailers.

In this paper, I would like to only consider the strategy of international format transfer into developing countries during the internationalization process. In other words, how should international retailers transfer their retail format successfully to foreign countries by standardizing or adapting the internal

Manuscript received March 24, 2020; revised June 10, 2020.

Lehua Yang is with Graduate School of Economics, Kyoto University, Japan (e-mail: rakuka777@gmail.com). and external elements of their retail format?

The paper is organized in the following way. Firstly, a brief literature review approaches to international strategy, secondly present the conceptual framework to understand how international retailers transfer their retail format successfully. Thirdly, present a case study of UNIQLO retail internationalization experiences in Mainland China. Findings are then discussed, and I present a conclusion and point to directions for future research.

\section{LITERATURE REVIEW}

\section{A. Issue Underlying Format Transfer Strategies}

Retail format transfer is defined as the entity that is transferred abroad and consists of the basic parts of transfer of the external retail marketing program and transfer of internal retail systems and processes [3]. In this paper, I would like to use the term "front-end operations" to refer to external retail marketing, and the term "back-end operations" to refer to internal retail systems and processes.

Some researchers have discussed the internationalization strategies followed by retailers within a few decades. Dawson [7] and Goldman [8] indicated that the failure of international expansion plans is often format related. Some researchers have focused their investigations on the internationalization strategy patterns. Salmon and Tordjman [9] were interested in the specificities and similarities of the European markets to identify strategies of geographical diversification. And they identified two types of retailers for international retail expansion that they termed "global" and multinational". Global retailers expand internationally using a standard retail format such as IKEA and Benetton, which allows savings from economies and efficiencies of scale. Especially, in the early studies, some international retailing literature tends to emphasize the importance of the more tangible, economic advantages (scale and standardization) largely ignoring the others [8], [10]. On the other hand, Multinational retailers such as BAT adapt their retail offering to suit local conditions and demand.

However, some researchers argued that even global retailers are forced to adapt their retail format to a certain extent, especially they often use a standardized marketing mix at first and adapt to local conditions afterward [11]-[13]. Treadgold [14] emphasized that a middle course may be termed "transnational" retailing, whereby the company seeks to achieve global efficiency while responding to local needs and constraints. And Treadgold illustrates three major types of development position, providing examples of each in Fig. 1. Yahagi [13] also points out that complete standardization is possible only in exceptional cases such as luxurious brand 
shops. In most cases of localization of retail stores, some degree of adaptation always occurs. Thus, recently, some researchers argue that the "Glocalization" or "Hybridization" approach should be considered in the internationalization strategy [16], [17].

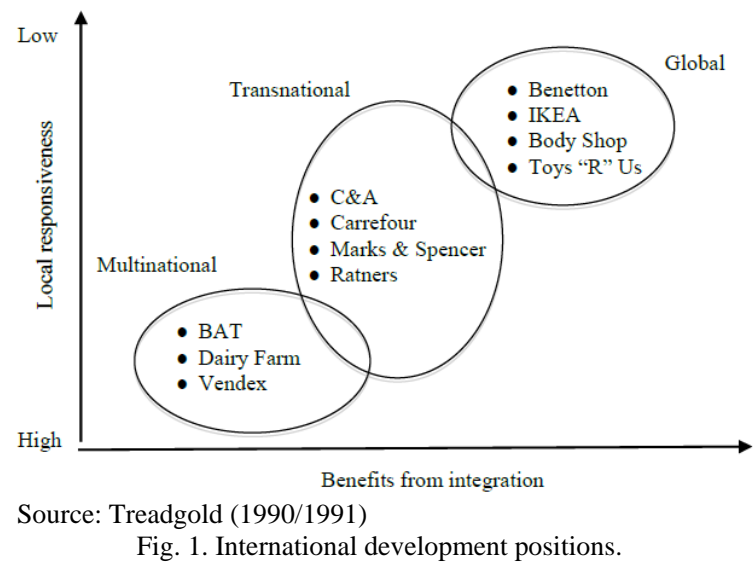

However, although some researchers have categorized the types of international strategy, there is still a lack of knowledge regarding the competitive advantage for the standardization and adaptation in international retailers. For example, Treadgold [18] underlines the competitive advantages, which explains the entry of retailers into a foreign country. Thus, rather than seeing an international strategy as a simple matter of replicating formats or adapting formats to new markets, the author distinguishes the factors which together are of importance in establishing whether a retailer develops competitive advantages in international operations.

\section{B. Conceptual Framework}

The conceptual framework Strategic hybridization of retailing presented here has elements of earlier theories and concepts (Fig. 2). For example, Dunning's Eclectic Theory [19] focuses on ownership-specific advantages, location-specific advantages, and internalization-specific advantages. Also, the integration-responsiveness (I-R) framework has examined format transfer from different perspectives by Bartlett and Ghoshal [20]. And, some researchers focus on an innovative and original business model, rather than a simple replica of the original in existing internationalization strategy patterns.

Although Dunning's three factors approach developed for manufacturing firms, the factor of ownership-specific advantages may have relevance to the study of the retailing sector [7], [21]. Ownership-ship specific means the firm has an innovatory product, process or business method which gives to the firm competitive advantage in the market. Some researchers apply it to retailing and provide some examples. For example, unique products or a global brand image (Body Shop, Laura Ashley), and an individually refined sales method (ALDI, Benetton, McDonald's) were mentioned [22], [23]. Thus, entry into host markets is most successful when the expansion opportunity builds on the retailer's core bases of competitive advantage.

Although successful international retailers build on their core competencies, they also recognize cultural differences and adapt their core strategy to the needs of local markets. In other words, adaptability is one of the keys to success in international retailing. For example, store designs and layouts often need to be adjusted in different parts of the world. And government regulations and cultural values can also affect store operations. However, adaptation is necessary, but once retailers adapt the local environment, it would lose their competitive strength of their formats. For instance, Goldman [7] found that retailers facing Chinese retailers operating the same formats felt adaptation to Chinese conditions would dilute the competitive strength of their formats. Thus, how to adapt the local markets and build a sustainable competitive advantage is a key issue in the international operations.

Yahagi and M. Kar [24] points that the idea of "creative adaption" is not found in existing internationalization strategy patterns, and they apply the concept of "continuous creative adaptation" to the case study which the transfer from the US to Japan happened within the pattern of continuous creative adaptation.

Coe and Lee [25] argue that the strategic localization of transnational retailers needs to be conceptualized as a dynamic that evolves over time after initial inward investment. To sum up, past studies indicate that retail formula may be viewed as "culture bound", which means that barriers may result from a "mismatching" between host market environment and the exported retail formula [26]. Thus, retailers need to transfer and design their format dynamically by using different strategies in the foreign market. The conceptual framework presented in this paper is based on theses concepts and studies mentioned above. In other words, the Strategic hybridization of retailing means that the basic strategies of standardization and adaptation between country homogeneity and heterogeneity in home and host countries are significant during the format transfer. Meanwhile, the strategies of competitive advantages should be considered through the leverage "specific advantages" from global operations and "creative adaptation" from local operations.

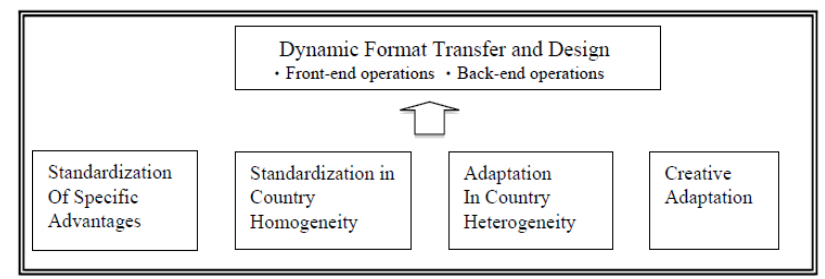

Source: Own creation.

Fig. 2. Analytical framework.

\section{DATA SOURCE AND ANALYTICAL MethodS}

\section{A. Data Source}

In this paper, I will use a Japanese retailer, namely, UNIQLO as my example but believe that the conceptual framework is relevant to the international expansion of retailers in other parts of the world. The case study of UNIQLO Mainland China is based on secondary sources. A systematic review of published data in Mainland China and Japan about the operation of the UNIQLO retailer in Mainland China was conducted. It included annual reports, company documents, business publications, and newspapers 
for the period of 2002-2019. Meanwhile, the consumer, staff interviews were implemented many times during the last three years, helps in understanding why UNIQLO succeed in Mainland China.

\section{B. Analytical Methods}

The aim of the analysis is to develop theory and to understand how international retailers transfer their retail format successfully to foreign countries in a long-term process by standardizing or adapting the internal (Back-end operations) and external (Front-end operations) elements of their retail format (Table I). Thus, we need to outline which format elements they transferred and adapted. Meanwhile, to find out the competitive advantages for the standardization and adaptation they have.

\section{TABLE I: ELEMENTS OF RETAILING}

\begin{tabular}{ll}
\hline \hline External elements & Internal elements \\
\hline -Retail brand & -Purchasing systems/procedures \\
-Store layout and store design & -Relationships with key suppliers \\
-Store location & -Logistics and warehouse systems \\
-Assortment & -Distribution logistics for stores \\
-Private labels & -Warehouse management \\
-Price & \\
-Retail communications & \\
-Customer Service & \\
-Online sales & \\
\hline \hline
\end{tabular}

\section{SAMPLE}

\section{A. Apparel Retailing in Mainland China}

According to daxue consulting, sales in Mainland China's apparel market have reached over CNY 2,077 billion in 2018, growing at $7.8 \%$ YOY, which is the fastest growth rate since 2014. It is predicted that in 2019, Mainland China will replace the US as the world's largest apparel market. On the other hand, sales of the fast fashion industry in Mainland is in significant growth, as international brands continued their aggressive expansion and gained more share of the market such as The Gap, ZARA, H\&M, and UNIQLO with their international expertise and vanguard technology.

In Mainland China, these retail chains from developed markets have become important competitors and market leaders. At the same time, the fast fashion market in Mainland China is facing the challenges of domestic competition. For instance, the local competitors such as MJ-Style and HLA have not only quickly risen in the market with several strategy changes, rapidly impacting the international fast-fashion brands, but also expanded overseas. On the other hand, fast fashion retailers are facing the challenges of quality-oriented consumption upgrade. Thus, not all of the fast-fashion retailers are plain sailing. Some retailers such as Honeys and Forever 21 have withdrawn from Mainland China in 2018 and 2019.

\section{B. UNIQLO Mainland China}

UNIQLO, the primary subsidiary of Japanese retail holding company Fast Retailing, first appeared as a brand in Hiroshima in 1984, and by 1994 there were 100 UNIQLO stores in its home country. However, it wasn't until almost a decade later that UNIQLO decided to venture into other countries in 2001. And it had 827 stores in Japan and 1,241 stores from oversea at the end of August in 2018 (Table II).
Besides, UNIQLO also was the first company in Japan to establish a SPA business model, which called Specialty store retailer of Private label Apparel model encompassing all stages of the business-from design and production to final sale. Base on it, UNIQLO, with its Life-Wear concept of ultimate everyday comfort, differentiates itself by offering unique products such as sweaters made from superior-quality cashmere, supima cotton T-Shirts, and ranges incorporating original HEATTECH and Ultra Light Down technologies.

UNIQLO opened its first store in Shanghai, China in 2002. By August 2018, the company has operated 633 stores in all regions of Mainland China expect of Tibet. Mainland China has become the second-largest market for UNIQLO only after Japan. Next, according to market research provider Euromonitor International, UNIQLO's market share climbed from 0.7 percent to 1.2 percent in the Chinese market from 2014 to 2018, while fashion retail brand H\&M and Zara took only 0.4 and 0.5 percent in 2018. Besides, UNIQLO has been ranked the No.1 apparel brand in the "Top Brand in China" awards given by the influential CBN China Weekly magazine since 2011. That is clear proof of the strong respect many Chinese customers have for the UNIQLO brand.

Here, I think UNIQLO is a good example to discuss and I would like to focus on the major activities of front-end operations and back-end operations by using the concepts I mentioned above.

TABLE II: UNIQLO INTERNATIONAL STORES

\begin{tabular}{|c|c|c|}
\hline $\begin{array}{l}\text { Units: } \\
\text { Stores }\end{array}$ & $\begin{array}{l}\text { As of August } \\
31,2018\end{array}$ & Country \& Region \\
\hline Europe & 78 & $\begin{array}{l}\text { UK (11), France (25), Russia (31), } \\
\text { Germany (5), Belgium (3), Spain (2), } \\
\text { Sweden (1) }\end{array}$ \\
\hline $\begin{array}{l}\text { Greater } \\
\text { China }\end{array}$ & 726 & $\begin{array}{l}\text { Mainland China (633), Hong Kong (28), } \\
\text { Taiwan (65) }\end{array}$ \\
\hline $\begin{array}{l}\text { South } \\
\text { Korea }\end{array}$ & 186 & South Korea (186) \\
\hline $\begin{array}{l}\text { Southeast } \\
\text { Asia \& } \\
\text { Oceania }\end{array}$ & 198 & $\begin{array}{l}\text { Singapore (26), Malaysia (48), Thailand } \\
\text { (40), Philippines (51), Indonesia (18), } \\
\text { Australia (15) }\end{array}$ \\
\hline $\begin{array}{l}\text { North } \\
\text { America }\end{array}$ & 53 & USA (48), Canada (5) \\
\hline Total & 1,241 & 19 \\
\hline
\end{tabular}

\section{RESEARCH AND FACT FINDINGS}

\section{A. Front-End Operations}

Firstly, in the production section, unlike trend-chasing apparel firms such as ZARA and H\&M who focus on fashion and quantity, the UNIQLO brand seeks to become an essential part of life, which is high-quality, innovative clothing that emphasizes functionality and quality. It develops radical new materials together with the world's best fabric technology innovators and creates basic designs using superior natural materials that their products cannot be copied or replicated.

In Mainland China, more Chinese consumers embraced the UNIQLO LifeWear concept, especially a large number of the middle class who are more interested in quality and function wear than fast fashion. For instance, many customers support classic designs that are less affected by functionality and fashion, such as heat-insulated underwear, HeatTech, and Ultra Light Down. Meanwhile, some products 
that collaborated with famous designers and works are also very popular in Mainland China. For example, UNIQLO has released the $\mathrm{t}$-shirt designs in a special partnership that celebrates the 50th anniversary of Japan's iconic manga magazine Weekly Shonen Jump in 2018, which was almost sold out in just 10 minutes online and sold out in 2 hours at physical stores in Mainland China.

Secondly, as we all know that the hospitality of Japanese companies is highly evaluated all over the world. UNIQLO has decided to transfer its hospitality into Mainland China in the same way as in Japan and received a positive evaluation. For instance, they trained staff to bow with a smile, display the refolding, while there are still a few competitors realized the importance of customer service in Mainland China. In other words, UNIQLO is improving its brand image by taking advantage of its home country hospitality and placing more emphasis on politeness than local competitors.

Thirdly, the store interior design is in the same style as UNIQLO stores within commercial facilities in Japan. It was painted white to exude a feeling of clear, pure freshness.

Fourthly, it is well known that flagship stores can be a strategic way of market entry of foreign markets [27]. UNIQLO has opened many flagship stores in the world's major cities to express the very best of them as in Japan. In Mainland China, UNIQLO opened its 4th global flagship in Shanghai West Nanjing Road, following New York, London, and Paris in 2010. After that, UNIQLO opened more than 4 global flagship stores in other major cities of Mainland China such as Beijing, Guangzhou, and Shenzhen in the past decade. As a result, through those flagship stores, UNIQLO has successfully shared its brand message of quality, style, and value with the Chinese. It also raised awareness of their brand and recognition of what UNIQLO stands for rapidly.

\section{UNIQLO Mainland China Stores}$$
2005201020112012201320142015201620172018
$$

Fig. 3. UNIQLO mainland China stores.

Fifth, UNIQLO open stores faster than in Japan and other markets. As is shown in Fig. 3, approximately 80 stores have been opened annually since 2012, and 673 stores have already been opened in 2018, which is very rapid. Unlike in Japan, Mainland China has vast land and a large population, the "critical mass strategy" which focus on the speed of opening stores is very important and necessary. Due to the fast expansion, UNIQLO can quickly increase brand awareness across Mainland China and has become a hugely popular foreign apparel brand in recent years.

However, although Chinese consumers embraced the
UNIQLO "LifeWear" concept, the product assortment is never unified as Japan. Firstly, Mainland China has vast land and the climate of the country is difficult to describe. For instance, the southernmost parts of the country are almost tropical, while the northernmost part is subarctic. It is necessary to carefully consider the timing of the new product launch and production assortment in each region. For this reason, UNIQLO has the decision to introduce tailored product mixes in different regions of Mainland China and facilitated the timely delivery of the items that customers needed most. They also emphasized "individual store management" to create a product mix for each region. Moreover, given the large market order and uneven area distribution, UNIQLO adopts a weekly calculation scheme to check the stock.

Next, Mainland China's online retail market has expanded rapidly for more than a decade. According to the National Bureau of Statistics of China, Mainland China's online retail spending exceeded RMB 9 trillion in 2018, and it has ranked first globally for six consecutive years. While other foreign apparel firms still focus on physical store operations, UNIQLO has launched an online store on the Alibaba's TAOBAO (T-mall) shopping mall. Due to TAOBAO has become Mainland China's largest consumer e-commerce company and has internet technologies, resources, and experience, UNIQLO decided to build a strategic partnership to launch the online sales with TABAO in 2009.

Meanwhile, UNIQLO was the first clothing brand to embrace T-mall in 2009, while other leading competitors opened online stores on T-mall slowly. For example, Zara and H\&M decided to open their online stores on T-mall unit 2014 and 2018, respectively. Besides, to give consumers a better online approach, UNIQLO has allowed its online customers to pick up their orders at a store since 2016. By the time of 2018, UNIQLO has made it possible to choose whether to purchase immediately or receive it at any time. As a result, UNIQLO has a huge success in online sales that it accounts for approximately $20 \%$ of overall sales in Mainland China, while it was only accounted for $9.9 \%$ of total sales in Japan in FY2019.

Furthermore, UNIQLO has for the first time launched a "Digital Experience Pavilion" that integrates both online and offline, real-world and virtual in Shenzhen. There are four major concept zones, including "Classic Quality Wardrobes", "Healthy Life Gas Station", "Tide Fun Culture and Creation Museum" and "24-hour Living Space", which combines stylish functionality with relaxed leisure. In addition, the store has a digital experience hall where you can enjoy shopping by using cutting-edge technologies such as virtual fitting, 4D technology, and payment in conjunction with smartphones.

In other words, UNIQLO is actively adopting advanced technologies in the Chinese market and providing innovative consumer experiences. This was reiterated by the Chief Marketing Officer for UNIQLO Mainland China, who in an interview in 2019 started:

We have a very powerful platform in terms of e-commerce, and we have more than 100 million fans in China... In a sense, we think we have great power to integrate the consumer's needs and provide them an online to offline solution. 


\section{B. Back-End Operations}

It is well known that some retailers have already overcome the issue of local procurement through the SPA model (for specialty-store/retailer of private-label apparel) before going abroad.

Firstly, UNIQLO can secure stable, high-volume supplies of top-quality materials at a low cost by negotiating directly with materials manufacturers and placing large-volume orders. They also partner with Toray Industries, a world-leading synthetic fiber manufacturer, to create innovative high-function materials and products such as HeatTech. Meanwhile, they outsource all production to partner factories not only in Mainland China, but also in countries such as Vietnam, Bangladesh, and Indonesia. In other words, UNIQLO has already built its procurement system and production network when it enters the Chinese market, and this why it can transfer its competitive advantage into the Chinese market.

Secondly, UNIQLO began to transfer its automated Ariake warehouse into Mainland in 2019, which has been running for two years in Japan. The Ariake warehouse aims to reduce the time from design to production and production lead times and overhauling their logistics systems. Especially in Mainland China, which has a large land area, stores will play the role of EC warehouses, and it will be able to deliver purchased products as quickly as possible while placing store inventory in orders. On the contrary, although many companies are interested in online and offline in Mainland China, there are still only a few companies that can establish an Omni-channel like UNIQLO's automated Ariake warehouse.

Thirdly, in the logistics systems, UNIQLO is closely related to Daifuku Co in Japan, which is the world's leading provider of material handling systems to the factory and distribution, cleanroom, automotive, airport, and general industry markets. For instance, they have established a strategic partnership to "reform and improve logistics" and to build the world's most advanced automated facilities with the aim of full automation in the brand's Japanese and overseas warehouse since 2016.

However, in Mainland China, UNIQLO is teaming up with logistics company ITOCHU Logistics Co, one of the core operating companies of the ITOCHU Group. Comparing with Daifuku, ITOCHU's Logistics Services Department has placed importance on domestic demand-based logistics in Mainland China early on and there are about 96 logistics bases have been established throughout the country now. Nowadays, many of UNIQLO's products transport for the Shanghai distribution center, which with about 70,000-sqm floor area. In this case, I found that UNIQLO did not use the same supply system as in Japan but selected an optimal logistics company that suits the local situation.

\section{DISCUSSION}

As Goldman [8] mentioned, format transfers turned out to be much more complex and varied than previously described. In this case, UNIQLO has transferred some of the activities from its home country and has localized the format to tailor to the Chinese market, which is in a different business environment from the Japanese market. However, they not just leverage global advantages and to adapt to local conditions. Our findings are shown in Table III, suggest that during the localization process, UNIQLO has thoroughly pursued four strategies to build a dynamic format successfully.

Firstly, they transfer as many as possible of the external offering and internal elements that were homogeneous between Japan and Mainland. For instance, the store interior design and flagship store strategy are the same as Japan. However, although they can transfer those elements directly, other competitors may have existed or imitated their strategies as soon as possible. Thus, they have to ensure that their specific advantages can be transferred. In this case, we found that UNIQLO has many specific advantages that can be transferred to the Chinese market. For example, own product, the supply chain and the automated Ariake warehouse which are their competitive advantages in Mainland China.

Secondly, they also try to adapt to local conditions due to the country's heterogeneity among Japan and Mainland China. The product assortment and "individual store management" are good examples in this case. However, those are the strengths of the local competitors because they understand customer needs and the local environment more than international retailers. Therefore, UNIQLO has realized the importance of creative adaptation. They decided to build a strategic partnership to launch online sales with Alibaba and launched a "Digital Experience Pavilion" to satisfy the customers" needs.

TABLE III: HYBRIDIZATION STRATEGIES IN MAINLAND CHINA

\begin{tabular}{lll}
\hline \hline Types of Strategies & & \multicolumn{1}{c}{ External and Internal Elements } \\
\hline Standardization & of & Unique Product, Japanese Hospitality \\
Specific Advantages & & $\begin{array}{l}\text { Purchasing Systems, Automated Warehouse } \\
\text { Standardization } \\
\begin{array}{l}\text { Country Homogeneity } \\
\text { Adaptation in Country }\end{array}\end{array}$ \\
$\begin{array}{l}\text { Heterogeneity } \\
\text { Creative Adaptation }\end{array}$ & Assortment, Logistics Systems \\
\hline \hline
\end{tabular}

\section{CONCLUSION}

Retailers have been aggressively internationalizing for three decades. Many researchers have indicated that the debate about standardization and adaptation of retail format transfer is a key issue in the field of retail internationalization. Many empirical studies point out that the failure of international expansion plans is often format related. However, although some researchers have categorized the types of international strategy, there is still a lack of knowledge regarding the competitive advantage for the standardization and adaptation in international retailers. Meanwhile, we need to develop a retail-specific theory to understand why retailers can operate their business successfully in the host country with many competitors.

For this purpose, based on earlier theories and studies, I propose, based on earlier theories and studies, I propose the conceptual framework Strategic hybridization of retailing for understanding how should international retailers transfer their retail format successfully to foreign countries by standardizing or adapting the internal and external elements 
of their retail format. The author also uses a Japanese retailer UNIQLO as a case study to test whether the conceptual framework is useful. As a result, it is important to point out that retailers seeking to internationalize need to give detailed consideration to the processes of localization with four strategies mentioned above. They need to realize the country's homogeneity and heterogeneity between home and host countries. Meanwhile, retailers should standardize more elements with specific advantages and adapted more elements creatively in a host country. In other words, the specific advantages elements and creative adaptation elements are the key points to help in understanding why retailers do succeed in all international markets.

Also, a deep analysis is required to understand the determinant of standardization and adaptation. Meanwhile, more empirical analysis is required to determine whether the conceptual framework can be proven.

\section{CONFLICT OF INTEREST}

The authors declare no conflict of interest.

\section{REFERENCES}

[1] S. C. Hollander, Multinational Retailing, East Lansing, MI: Michigan State University Press, 1970.

[2] C. Waldman, Strategies of International Mass Retailers, New York, Praeger, 1978.

[3] A. Goldman, "Transfer of a retailing technology into the less developed countries: The supermarket case," Journal of Retailing, vol. 57 , pp. 5-29, 1981.

[4] M. Kacker, Transatlantic Trends in Retailing, Westport, CN: Quarum Books, 1985.

[5] R. Raymond, "International investment and international trade in the product cycle," Quarterly Journal of Economics, vol. 80, pp. 190-207, May, 1966.

[6] J. H. Dunning, "The eclectic paradigm of international production: A restatement and some possible extension," Journal of International Business Studies, vol. 19, pp. 1-31, 1988.

[7] J. Dawson, "Internationalization of retail operations," Journal of Marketing Management, vol. 10, pp. 267-282, 1994.

[8] A. Goldman, "The transfer of retail formats into developing economies: The example of China," Journal of Retailing, vol. 77, no. 2, pp. 221-242, 2001

[9] W. J. Salmon and A. Tordijman, "The internationalization of retailing," International Journal of Retailing, vol. 4, no. 2, pp. 3-16, 1989.

[10] S. Segal-Horn and H. Davison, "Global Markets, the global consumer and international retailing," Journal of Global Marketing, vol. 5, no. 3 , pp. 31-61, 1992.

[11] T. Levitt, "The globalization of markets," Harvard Business Review, May-June 1983.

[12] A. Jonsson and N. J. Foss, "International expansion through flexible replication: Learning from the internationalization experience of
IKEA,” Journal of International Business Studies, vol. 42, no. 9, pp. 1079-1102, 2011.

[13] J. Gamble, "Transferring organizational practices and the dynamics of hybridization: Japanese retail multinationals in China," Journal of Management Studies, vol. 47, no. 4, pp. 705-732, 2010.

[14] A. D. Treadgold, "The emerging internationalisation of retailing: Present status and future challenges," Irish Marketing Review, vol. 5, no. 2, pp. 11-27.

[15] T. Yahagi, Retail Internationalization Process, Tokyo: Yuhikaku, 2007.

[16] J. Matusitz, "A giant retailer in Argentina: 'Glocalization' Perspectives," Portuguese Journal of Social Science, vol. 15, no. 1, pp. 111-127, 2016

[17] L. Q. Siebers, "Hybridization practices as organizational responses to institutional demands: The development of western retail TNCs in China," Journal of Economic Geography, vol. 17, no. 1, pp. 1-29, 2017.

[18] A. D Treadgold, "The developing internationalization of retailing," International Journal of Retail \& Distribution Management, Vol.18, no.2, pp. 4-11, 1990.

[19] J. H. Dunning, International Production and the Multinational Enterprise, London: Allen \& Unwin, 1981.

[20] C. Bartlett and S. Ghoshal, Managing Across Borders: The Transnational Solution, Harvard Business School Press, Boston, 1989.

[21] J. H. Dunning, International Production and the Multinational Enterprise, London: Allen \& Unwin, 1981

[22] L. Pellegrini, "The internationalization of retailing and 1992 Europe," Journal of Marketing Channels, vol. 1 no. 2, pp. 3-27, 1991.

[23] E. Howard, "Competing on a global scale," European Retail Digest, vol. 25, pp. 6-8, 2000.

[24] T. Yahagi and M. Kar, "The process of international business mode transfer in the Seven-Eleven group: US - Japan - China," Asia Pacific Business Review, vol. 15, no. 1, pp. 41-58, 2009.

[25] N. M. Coe and Y. S. Lee, "The strategic localization of transnationa retailers: The case of Samsung-Tesco in South Korea," Economic Geography, vol. 82, no. 1, pp. 61-88, 2006.

[26] K. Hutchinson, B. Quinn, N. Alexander, and A. M. Doherty, "Retailer internationalization: Overcoming barriers to expansion," The International Review of Retail, Distribution and Consumer Research, vol. 19, no. 3, pp. 251-272, 2009.

[27] E. Arrigo, "The role of the flagship stores location in luxury branding. An international exploratory study," International Journal of Retail \& Distribution Management, vol. 43, no. 6, pp. 518-537, 2015.

Copyright $(92020$ by the authors. This is an open access article distributed under the Creative Commons Attribution License which permits unrestricted use, distribution, and reproduction in any medium, provided the original work is properly cited (CC BY 4.0).

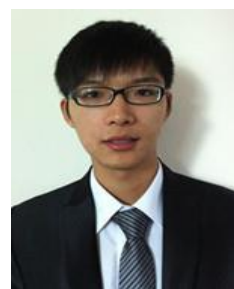

Lehua Yang was born in Guangdong, China. He is a Ph.D. student at Kyoto University, Japan. His research interests are internationalization of retailing and the development of private brands. 